\title{
CHARACTERISTICS OF LEACHATE AT IHIAGWA DUMPSITE, IMO STATE NIGERIA AND THEIR IMPLICATIONS FOR SURFACE WATER POLLUTION
}

\author{
Nelson-Kalu, C.T ${ }^{1}$; Amangabara, G.T ${ }^{1}$; Owuama, C.O. ${ }^{1}$, Nzeh, C.N and Uyo, C.N \\ Department of Environmental Management, Federal University of Technology, Owerri. \\ Nelsonkaluc@gmail.com, gordon.amangabara@futo.edu.ng
}

\begin{abstract}
Open dumpsite is the most common way to eliminate solid urban wastes in this part of the world. An important problem associated to landfills and open dumpsite is the production of leachates. The leachates from these dumpsites have many toxic substances, which may adversely affect the environmental health. Thus in order to have a better management of characteristics of Ihiagwa-Nekede waste dump leachates, representative leachate samples were collected and analyzed for Physico-chemical properties and levels of heavy metals in them. Results indicate pH7.38, temperature $28.30{ }^{\circ} \mathrm{C}-28.40^{\circ} \mathrm{C}$, total dissolved solid $124.01 \mathrm{mg} / \mathrm{l}-125.45 \mathrm{mg} / \mathrm{l}$, magnesium hardness $4.40 \mathrm{mg} / \mathrm{l}-7.32 \mathrm{mg} / \mathrm{l}$, sulphate $3.60 \mathrm{mg} / \mathrm{l}$ $3.70 \mathrm{mg} / \mathrm{l}$, and nitrate $27.00 \mathrm{mg} / \mathrm{l}-27.60 \mathrm{mg} / \mathrm{l}$. Other parameters indicated as follows Conductivity $1910 \mu \mathrm{s} / \mathrm{cm}-1930.00 \mu \mathrm{s} / \mathrm{cm}$, total chloride $891.72 \mathrm{mg} / \mathrm{l}-891.74 \mathrm{mg} / \mathrm{l}$, carbonate $1708.00 \mathrm{mg} / \mathrm{l}-1904.00 \mathrm{mg} / \mathrm{l}$, Ammonia $9.39 \mathrm{mg} / \mathrm{l}-9.40 \mathrm{mg} / \mathrm{l}$, calcium hardness $373.17 \mathrm{mg} / \mathrm{l}$ $375.61 \mathrm{mg} / \mathrm{l}$, total solid $2423.00 \mathrm{mg} / \mathrm{l}-2454.00 \mathrm{mg} / \mathrm{l}$, phosphate $13.52 \mathrm{mg} / \mathrm{l}-13.54 \mathrm{mg} / \mathrm{l}$. The heavy metal: cyanide $2.25 \mathrm{mg} / \mathrm{l}-2.33 \mathrm{mg} / \mathrm{l}$, zinc $18.08 \mathrm{mg} / \mathrm{l}-18.38 \mathrm{mg} / \mathrm{l}$, copper $19.90 \mathrm{mg} / \mathrm{l} 20.48 \mathrm{mg} / \mathrm{l}$, iron $10.67 \mathrm{mg} / \mathrm{l}-10.82 \mathrm{mg} / \mathrm{l}$, lead $1.27 \mathrm{mg} / \mathrm{l}-1.41 \mathrm{mg} / \mathrm{l}$, and manganese $3.00 \mathrm{mg} / \mathrm{l}-3.61 \mathrm{mg} / \mathrm{l}$, all these exceeded the WHO standards. The obtained results showed that the landfill leachates are characterized by high concentrations of heavy metals and other disease causing elements and therefore require urgent treatment to forestall the contamination of groundwater system and the nearby Otamiri River.
\end{abstract}

Keywords: Leachates, landfill, waste dumpsites, heavy metals, Ihiagwa, Nekede, MSW 


\section{INTRODUCTION}

Solid waste management has been a major problem in the world especially in most developing countries (Rahman et al., 2013). The problem is exacerbated by the lack of wellorganized waste management strategy. Most major cities have no functional waste management system. Traditionally, most domestic and industrial wastes are disposed directly either into open dump sites which are often subjected to open incineration or into gutter drains, rivers and swamps. The increasing volume of municipal solid waste in Nigeria including Imo State, reflect the dramatic population growth, and its shift from rural areas to urban sector. This increase in waste generation has also increased the problem of how to get rid of it without causing undesirable impact on the environment and subsequently on public health.

Landfill and, in most developing countries open dumpsites or burrow pits are the most common methods used to dispose municipal solid residues. The waste dumped in this open landfills/burrow pits undergo biological, chemical and physical transformations which are controlled, among other influencing factors, by water input fluxes leading to three physical phases of waste composition: The solid phase (bio-solids), the liquid phase (leachate) and the gas phase. The liquid phase is enriched by solubilized or suspended organic matter and inorganic ions from the solid phase. In the gas phase mainly carbon (in the form of $\mathrm{CO} 2$ and $\mathrm{CH} 4)$. The Leachate generated from such containment sites is known to contain many complex organic and inorganic pollutants.

Leachate is a widely used term in the environmental sciences where it has the specific meaning of a liquid that has dissolved or entrained environmentally harmful substance that may then enter the environment. It is most commonly used in the context of landfill of putrescible or industrial waste. However in the narrow environmental context, leachate is liquid material that drains from land or stockpiled material and contain significantly elevated concentration of undesirable materials derived from materials that it has passed through (Purwanta, 2007; Esmail et al., 2009; Etim and Onianwa, 2013). Therefore, leachate is any liquid that, in the course of passing through a landfill or open dumpsite has extracted dissolved and suspended matter. When water percolates through waste, it promotes and assists the process of decomposition by bacteria and fungi. This process in turn release byproducts of decomposition and rapidly use up any available oxygen, creating an anoxic environment. Landfill leachate may be characterized as water based solution of four groups of contaminants; dissolved organic matter (alcohol, acid, aldehydes, short chain sugar etc.), inorganic macro component (common cation and anions including sulfate, chloride, iron, aluminum, zinc and ammonia), heavy metals ( $\mathrm{Pb}, \mathrm{Ni}, \mathrm{Cu}, \mathrm{Hg}$ ), and xenobiotic organic compound such as halogenated organics (PCBs, dioxins, etc.) (Kjeldsen et al., 2002).

The presence of humic substance in leachate might enhance the transportation of heavy metals in addition the increase of ash content in landfill (Urase et al., 1997). In this respect, Huan-jung et al. (2006) analyzed the liquid output of three types of landfills, they pointed out that the active landfill leachates had high concentrations of the COD, volatile suspended solids, total TS, total organic carbon TOC, electrical conductivity and had high contents of $\mathrm{Fe}, \mathrm{Cr}$ and $\mathrm{Ni}$. The contamination of the natural environment from pollutants leaching from this dumpsite constitutes very serious problem because most landfill leachates contain a high concentration of organic matters and inorganic ions, including heavy metals (Baun et al., 
2000). There are sufficient evidences from the literature that the landfill leachates may cause a serious environmental problem by discharging heavy metals continuously, if it is not put under control (Poon and Chen, 1999; Abu-Rukah and Al-Kofahi, 2001; Nanny and Ratasuk, 2002; Huan-Jung et al., 2006 and Mor et al., 2006). The objective of this research at Ihiagwa - Nekede road open dumpsite therefore, is to examine and evaluate the landfill leachates to understand their characteristics and possible impact or threat to groundwater system and the nearby Otamiri river about $400 \mathrm{~m}$ away. The data obtained can help in the strategic management of landfills for reducing the risk of these landfills in the environment.

\section{MATERIALS AND METHODS}

\section{Study Area Description}
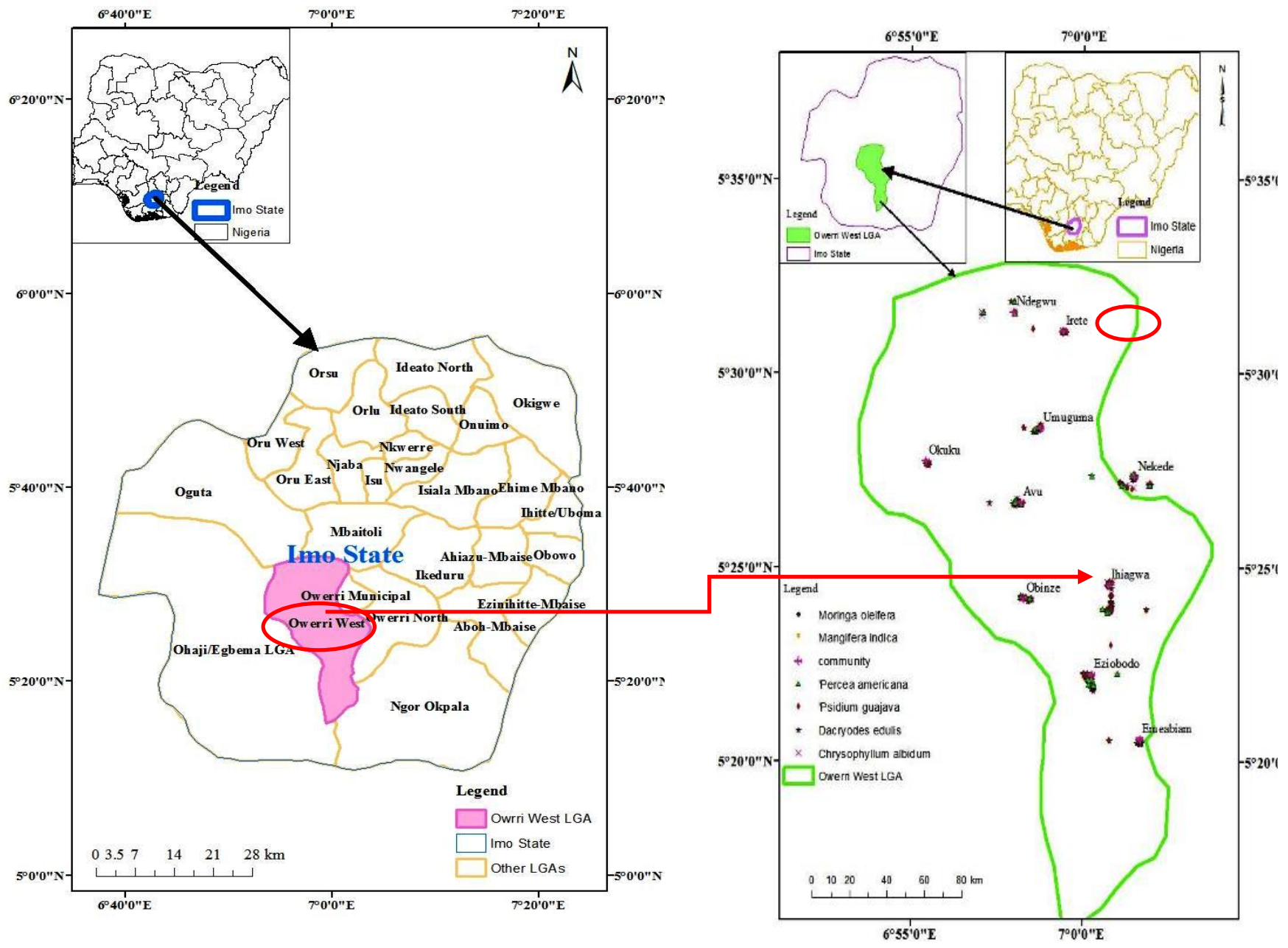

Fig 1.Map of Imo State showing the Study Area 
Ihiagwa is located at Lat. $5 \mathrm{~N}, \log .7 \mathrm{E}$ and altitude $156 \mathrm{~m}$ and $12 \mathrm{~km}$ South from Owerri capital, it is one of the communities in Owerri West Local Government of Imo State, Southeast Nigeria. Its population is over 10,000.

The prevalent climatic condition in the area is marked by two main regimes: the rainy and the dry seasons. The rainy season is from April to October during which the temperature varies from $25^{\circ} \mathrm{C}$ to $29^{\circ} \mathrm{C}$, and this season is associated with the prevalent moisture-laden south-west trade wind from the Atlantic Ocean. The wet season is also characterized by double maximum rainfall during which the first peak occur in July and the second occurs in September with a mean annual rainfall of $2152 \mathrm{~mm}$ (Ezeigbo, 1990). The dry season starts in November, when the dry continental north- eastern wind blows from the Mediterranean Sea across the Sahara desert and Samarian desert and down to the southern part of Nigeria. Humidity is usually low and clouds are absent, during the dry season. The effect of the harsh north easterly wind, also called Harmattan, is felt within the period. The average monthly temperatures are high throughout the year. A mean annual temperature of $31^{\circ} \mathrm{C}$ is typical of the area (Ezeigbo, 1990).The area lies within the tropical rain forest belt of Nigeria.The Benin formation which is an extensive stratigraphic unit in Southern Nigeria sedimentary basins underlies the study area. The area is also drained by the Otamiri River.

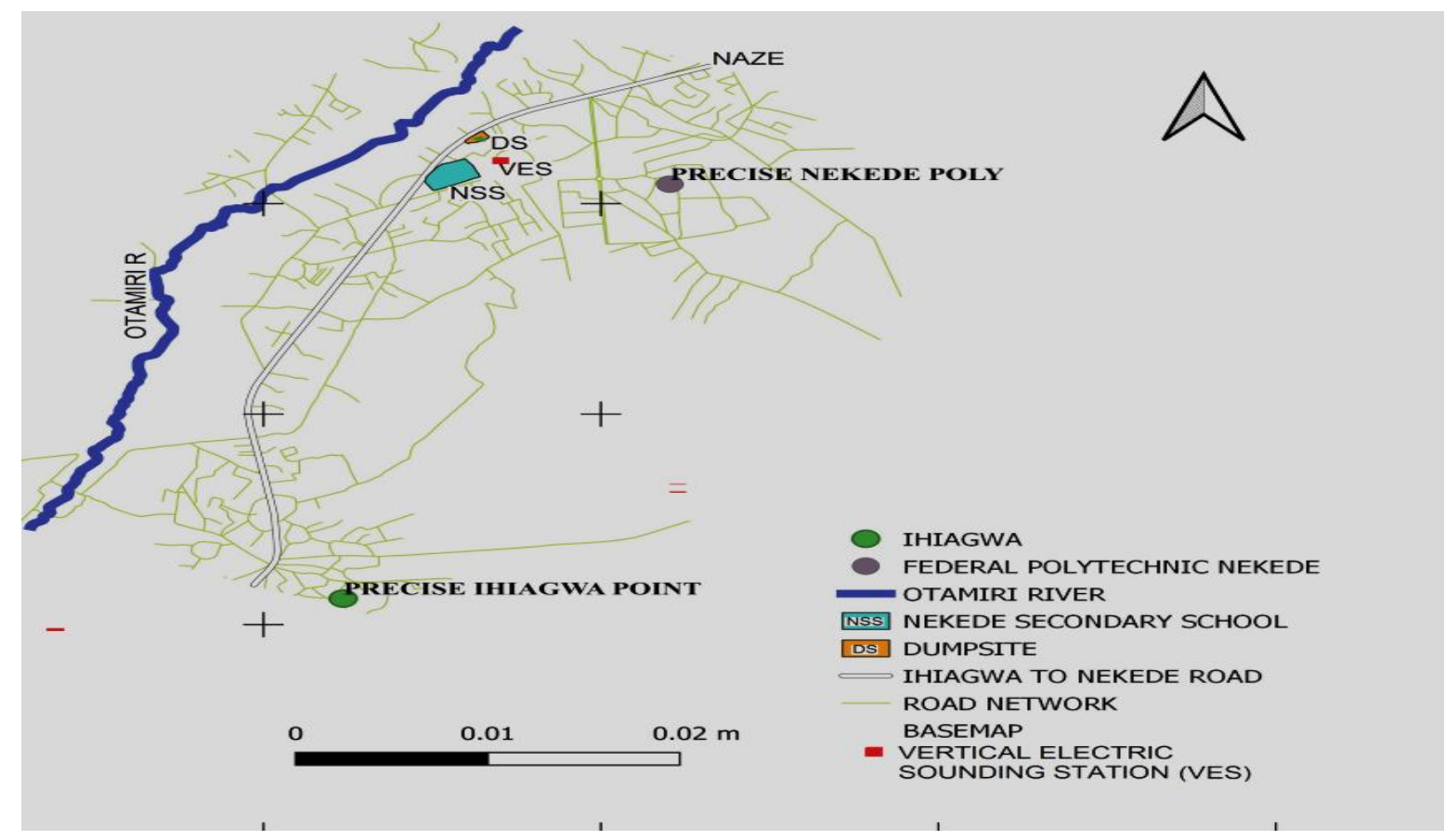

Fig. 2 Map showing location of dumpsite in relation to Otamiri river 
The waste dump site under study is open and along the Ihiagwa-Nekede Road. The increasing volume of waste is obviously contributed by increased population. Within these towns are the Federal Polytechnic, Nekede and the Federal University of Technology, Owerri both drawing a large number of students.

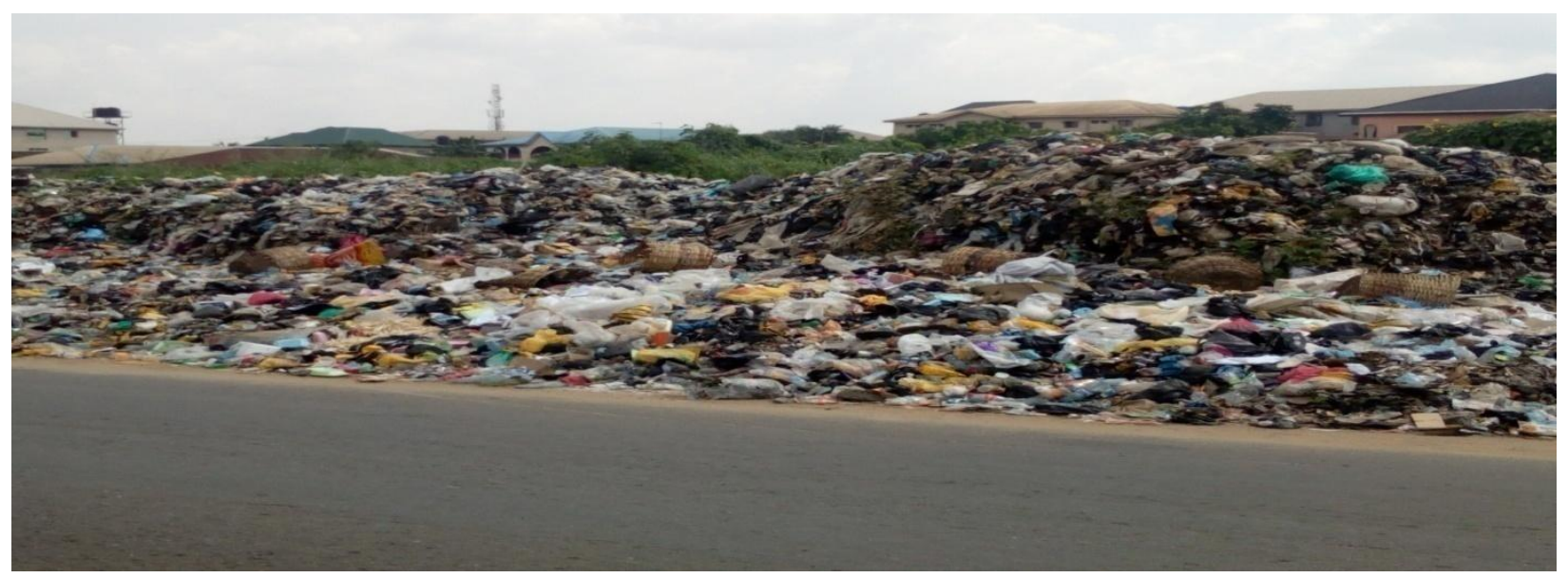

Fig 3. Nekede- Ihiagwa Road Open Dumpsite

\section{Sample Collection and Analysis}

Leachate samples were collected from the Nekede - Ihiagwa open dumpsite (Fig 3). Three different sites of leachate were selected. The first leachate sampling point is very close to the landfill (dug to a depth of $2 \mathrm{~m}$ ) upstream of the dumpsite area, whereas another two sampling points are about $15 \mathrm{~m}$ and $20 \mathrm{~m}$ respectively from landfill. Glass bottles were used to collect leachate for chemical analyses, whereas, samples preserved for BOD5 and COD tests were collected in polyethylene bottles covered with aluminum foils. In order to avoid chemical and biological changes that have the ability to change the natural state of the samples a few drops $(1 \mathrm{ml})$ of concentrated $\mathrm{HNO}_{3}$ was added to the sample meant for heavy metals analysis and $2 \mathrm{ml}$ concentrated $\mathrm{H}_{2} \mathrm{SO}^{4}$ added to samples for COD analysis to make the $\mathrm{pH}$ equal 2.0. The samples were then transported in a cool box to be stored under suitable temperature until analysis. Prior to leachate sample collection, the containers were rinsed with the samples in order to avoid contamination from externalities and acclimatize the containers to the sample environment. Twenty seven (27) parameters were measured using Atomic Absorption Spectrometer (AAS) for heavy metals and specified international standard organization method for water analysis.

\section{RESULTS AND DISCUSSION}

The results of the physico-chemical characteristics of the leachates are shown in (Tables $1 \&$ 2). Based on Table 2, parameters that do not meet quality standards according the World Health Organization (WHO) and the Nigeria Federal Ministry of Environment Guideline include Electrical Conductivity (EC), Sulphate, Total Chloride, Carbonate, Ammonia, Calcium hardness, TSS and TS. Ammonia levels that exceed the quality standards can impair respiratory tissues and cause odor in the water. 
Table 1: Physico-chemical characteristics of sampled leachates

\begin{tabular}{|c|c|c|c|c|c|}
\hline $\mathbf{S} / \mathbf{N}$ & PARAMETER & Location 1 & Location 2 & Location 3 & MEAN \\
\hline 1 & $\mathrm{pH}$ & 7.38 & 7.38 & 7.38 & 7.38 \\
\hline 2 & Temperature ${ }^{0} \mathrm{C}$ & 28.30 & 28.40 & 28.30 & 28.33 \\
\hline 3 & TDS, mg/l & 124.15 & 125.45 & 125.45 & 125.01 \\
\hline 4 & Conductivity, $\mu \mathrm{s} / \mathrm{cm}$ & 1910.00 & 1930.00 & 1930.00 & 1923.00 \\
\hline 5 & $\mathrm{DO}, \mathrm{mg} / \mathrm{l} \mathrm{O}_{2}$ & 4.00 & 3.90 & 3.90 & 3.93 \\
\hline 6 & $\mathrm{BOD}, \mathrm{mg} / \mathrm{l}$ & 3.60 & 3.70 & 3.70 & 3.66 \\
\hline 7 & $\mathrm{COD}, \mathrm{mg} / \mathrm{l}$ & 21.60 & 22.20 & 22.20 & 22.00 \\
\hline 8 & Sulphate, $\mathrm{mg} / \mathrm{l} \mathrm{SO}^{2-}{ }_{4}$ & 177.60 & 176.70 & 177.30 & 177.20 \\
\hline 9 & Total chloride, $\mathrm{mg} / \mathrm{l} \mathrm{Cl}^{-}$ & 891.72 & 891.74 & 891.72 & 891.73 \\
\hline 10 & Carbonate, $\mathrm{mg} / \mathrm{l} \mathrm{CO}_{3}^{-}$ & 1904.00 & 1708.00 & 1806.00 & 1806 \\
\hline 11 & Bicarbonate, $\mathrm{mg} / \mathrm{l} \mathrm{H} \mathrm{CO}_{3}^{-}$ & ND & ND & ND & \\
\hline 12 & Ammonia, $\mathrm{mg} / \mathrm{l} \mathrm{NH}_{3}$ & 9.39 & 9.40 & 9.40 & 9.39 \\
\hline 13 & Calcium hardness, $\mathrm{mg} / \mathrm{l} \mathrm{CaCO}_{3}$ & 373.17 & 375.61 & 374.39 & 373.39 \\
\hline 14 & Total hardness, $\mathrm{mg} / \mathrm{l} \mathrm{CaCO}_{3}$ & 380.49 & 380.49 & 380.49 & 380.49 \\
\hline 15 & Magnesium hardness, $\mathrm{mg} / \mathrm{l} \mathrm{CaCO}_{3}$ & 7.32 & 4.40 & 6.10 & 5.94 \\
\hline 16 & Total solid, mg/l TS & 2454.00 & 2438.00 & 2423.00 & 2438.33 \\
\hline 17 & Total suspended solid, mg/l TSS & 2329.85 & 2312.55 & 2297.55 & 2313.32 \\
\hline
\end{tabular}

Table 2: Leachate Sample results compared WHO and FMEnv. Standards

\begin{tabular}{|c|c|c|c|}
\hline PARAMETER & MEAN & $\begin{array}{l}\text { WHO } \\
\text { STD }\end{array}$ & FMENV STD \\
\hline $\mathrm{pH}$ & 7.38 & $6.5-8.50$ & $6.00-9.00$ \\
\hline Temperature ${ }^{0} \mathrm{C}$ & 28.33 & $20-30$ & NA \\
\hline TDS, mg/l & 125.01 & 500.00 & NA \\
\hline Conductivity, $\mu \mathrm{s} / \mathrm{cm}$ & 1923.00 & 100.00 & 125.000 \\
\hline $\mathrm{DO}, \mathrm{mg} / \mathrm{l} \mathrm{O}_{2}$ & 3.93 & NS & \\
\hline $\mathrm{BOD}, \mathrm{mg} / \mathrm{l}$ & 3.66 & NS & 30.000 \\
\hline $\mathrm{COD}, \mathrm{mg} / \mathrm{l}$ & 22.00 & NS & 75.000 \\
\hline Sulphate, $\mathrm{mg} / \mathrm{S} \mathrm{SO}_{4}^{2-}$ & 177.20 & 100 & 100.000 \\
\hline Total chloride, $\mathrm{mg} / \mathrm{l} \mathrm{Cl}^{-}$ & 891.73 & 250.00 & 100.000 \\
\hline Carbonate, $\mathrm{mg} / \mathrm{l} \mathrm{CO}_{3}^{-}$ & 1806 & 150.00 & \\
\hline Bicarbonate, $\mathrm{mg} / \mathrm{l} \mathrm{H} \mathrm{CO}_{3}^{-}$ & & 30.00 & \\
\hline Ammonia, mg/l $\mathrm{NH}_{3}$ & 9.39 & 0.30 & \\
\hline Calcium hardness, $\mathrm{mg} / \mathrm{l} \mathrm{CaCO}_{3}$ & 373.39 & 150.00 & \\
\hline Total hardness, $\mathrm{mg} / \mathrm{l} \mathrm{CaCO}_{3}$ & 380.49 & 150.00 & \\
\hline $\begin{array}{lll}\text { Magnesium hardness, } \mathrm{mg} / \mathrm{l} \\
\mathrm{CaCO}_{3}\end{array}$ & 5.94 & 150.00 & \\
\hline Total solid, mg/l TS & 2438.33 & $500-1500$ & \\
\hline Total suspended solid, mg/l TSS & 2313.32 & $<10.00$ & \\
\hline
\end{tabular}

The $\mathrm{pH}$ values for all three leachates are 7.38, 7.38 and 7.38 respectively. The value falls within the recommended WHO/FMEnv standard (table 3). The $\mathrm{pH}$ of the leachate samples tend to alkalinity according to the increasing age of the landfill (Alloway and Ayres, 2007). The $\mathrm{pH}$ of young landfill leachate is less than 6.5 while old landfill leachate has $\mathrm{pH}$ higher than 7.5 (Abass et al., 2009). Therefore, the $\mathrm{pH}$ value observed in this study represents an old 
waste dumpsite arising from biological stabilization of the organic matter present. The observed $\mathrm{pH}$ value can be attributed to the methane fermentation phase of the landfill. Kjeldsen et al. (2002) described this phase of decomposition of wastes by increased $\mathrm{pH}$ from 6.0 to 8.0 with the production of volatile fatty acids and carbon dioxide.

Electrical Conductivity (EC) values show variety results between three leachates. The least value is obtained at location $1(1,910.00 \mu \mathrm{S} \mathrm{cm}-1)$, while the highest value was obtained at both locations $2 \& 3(1,930.00 \mu \mathrm{S} \mathrm{cm}-1)$ with a mean of $1923.00 \mu \mathrm{S} / \mathrm{cm}$. EC measures the ionic strength of a material. The EC values exceeded the WHO/FMEnv standard of $1000 \mu \mathrm{S}$ $/ \mathrm{cm}$ and $125 \mu \mathrm{S} / \mathrm{cm}$ respectively. Increase in electrical conductivity is traced to the presence of chloride and potassium (Paul, 2004).

According to table 1, total dissolved solids (TDS), total suspended solids (TSS) and total solids (TS) were all detected in the leachate analysis. The separation of dissolved and suspended solids in water was accomplished by means of filtration. Al-Yaqout and Hamoda (2003), observed that the amount of TDS reflects the extent of mineralization and that its high concentration can alter both the physical and chemical characteristics of the receiving water body. The maximum value of TDS $125.45 / 125.15 \mathrm{mg} / \mathrm{l}$ with a mean of $125.01 \mathrm{mg} / \mathrm{l}$, falls below the WHO standard of $500 \mathrm{mg} / \mathrm{l}$. The TS had its maximum and minimum values as $2454.00 \mathrm{mg} / 1$ and $2423.00 \mathrm{mg} / \mathrm{l}$ with its mean value of $2438.33 \mathrm{mg} / \mathrm{l}$ which is far above the stipulated WHO standard of $500-1500 \mathrm{mg} / \mathrm{l}$. This could be traced to the presence of industrial waste. TSS maximum and minimum values were $2329.85 \mathrm{mg} / \mathrm{l} / 2297.55 \mathrm{mg} / \mathrm{l}$ with a mean value of 2313.32mg/l which is above the WHO/FMEnv standards.

The maximum and minimum values for dissolved oxygen were $4.00 \mathrm{mg} / \mathrm{l}$ and $3.90 \mathrm{mg} / \mathrm{l}$ respectively. This value is within the limit of WHO $(15 \mathrm{mg} / \mathrm{l})$. The biological oxygen demand (BOD) value of leachate tends to indicate the maturity of the landfill/dumpsite. The BOD value ranged from $3.60-3.70 \mathrm{mg} / \mathrm{l}$ with a mean value of $3.66 \mathrm{mg} / \mathrm{l}$. The mean value exceeds the recommended FMEnv standard of $30 \mathrm{mg} / 1$. The relatively elevated value might be due the activities of microbial activity on the decomposing materials that is yet to attain stability.

Sulphate, $\left(\mathrm{mg} / \mathrm{S} \mathrm{So}^{2-}{ }_{4}\right)$ the values from the samples examined ranged from $177.30-177.60 \mathrm{mg} / \mathrm{l}$ compared to the FMEnv/WHO standard of $100 \mathrm{mg} / \mathrm{l}$ possibly from the oxidation of iron sulphide present in the dumpsite. The value of chlorides in the leachate samples ranged from $891.72-89174 \mathrm{mg} / \mathrm{l}$ with a mean value of $892.73 .27 \mathrm{mg} / \mathrm{l}$. These values exceeded the FMEnv standard of $100 \mathrm{mg} / 1$ and WHO standard of $250 \mathrm{mg} / \mathrm{l}$. The concentration of chlorides may range between $200-3000 \mathrm{mg} / \mathrm{L}$ for a one or two years- old landfill with decrease in concentration to 100 for older landfill of about 5 to 10 years. However, it's observed in this study that the dumpsite is as old far more than 10 years.

The phosphates values ranged from $13.52-13.57 \mathrm{mg} / \mathrm{l}$ with a mean of $13.54 \mathrm{mg} / \mathrm{l}$. The mean value was observed to be above the WHO/FMEnv standards of $5.0 \mathrm{mg} / \mathrm{l}$. The presence of P04 in leachate is dangerous as its presence in water increases eutrophication and promotes the growth of algae. For Nitrate $\left(\mathrm{NO}_{3}, \mathrm{mg} / \mathrm{l}\right)$, normally a level of nitrate above the threshold of 45 $\mathrm{mg} / \mathrm{L}$ is a potential health risk to pregnant women and infants. This causes methaemoglobinemia. 
For alkalinity, the required doses of various chemicals depend on the alkalinity level of the water. Nathanson, (2000) indicated in his studies that high level of alkalinity unlike acidity tells of the presence of industrial or chemical pollution. The minimum and maximum values of alkalinity were $1708.00 \mathrm{mg} / \mathrm{l}-1904.00 \mathrm{mg} / \mathrm{l}$. These values were found to be above WHO standard of 100-200 mg/l. The FMEnv has no limit for this parameter. Alkalinity nature of the dumpsite can be traced to the methane fermentation phase of landfill. Kjeldsen et al. (2002) explained this phase of waste decomposition by $\mathrm{pH}$ 6.0- 8.0 with production of volatile fatty acids and $\mathrm{CO}_{2}$. Thus, landfill fire frequently occurs in site during dry season as a result of combustion.

Total Hardness, the value read $380.49 \mathrm{mg} / \mathrm{l}$ which is higher compared to WHO $(150 \mathrm{mg} / \mathrm{l})$. Calcium/Magnesium hardness values obtained are $373.17-375.61 \mathrm{mg} / \mathrm{l}$ and $7.32-6.10 \mathrm{mg} / \mathrm{l}$ respectively. The calcium values were above the limit stipulated by WHO whereas magnesium values were far below the recommended limit. However the presence of the compound has no detrimental health effect rather increases the hardness of water (WHO, 2009).

Results of the levels of heavy metals in leachate sample collected at Ihiagwa - Nekede Road dumpsite are shown in (Tables $3 \& 4$ ). The content of heavy metals such as Cyanide, magnesium, Zinc, Copper, Iron, Lead, nitrate, manganese and phosphate have different values from the various sampling point and all exceeded the WHO/FMEnv guidelines/quality standard.

Table 3 Levels of Heavy Metal in Leachates

\begin{tabular}{|l|l|l|l|l|l|}
\hline $\mathrm{S} / \mathrm{N}$ & Parameters & Location 1 & Location 2 & Location 3 & Mean \\
\hline 1 & Cyanide, $\mathrm{mg} / \mathrm{l} \mathrm{CN}^{-}$ & 2.33 & 2.25 & 2.33 & 2.30 \\
\hline 2 & Magnessium, $\mathrm{mg} / \mathrm{l} \mathrm{Mg}$ & 1.78 & 1.08 & 1.43 & 1.43 \\
\hline 3 & Zinc, $\mathrm{mg} / \mathrm{l} \mathrm{Zn}$ & 18.38 & 18.05 & 18.25 & 18.22 \\
\hline 4 & Copper, $\mathrm{mg} / \mathrm{l} \mathrm{Cu}$ & 20.48 & 19.90 & 20.19 & 20.19 \\
\hline 5 & Iron, $\mathrm{mg} / \mathrm{l} \mathrm{Fe}$ & 10.67 & 10.54 & 10.82 & 10.67 \\
\hline 6 & Lead, $\mathrm{mg} / \mathrm{l} \mathrm{Pb}$ & 1.27 & 1.41 & 1.34 & 1.34 \\
\hline 7 & Alkalinity, $\mathrm{mg} / \mathrm{l} \mathrm{CaCO}$ & 1904.00 & 1708.00 & 1806.00 & 1806.00 \\
\hline 8 & Nitrate, $\mathrm{NO}_{3}, \mathrm{mg} / \mathrm{l}$ & 27.20 & 27.00 & 27.60 & 27.26 \\
\hline 9 & Phosphate, $\mathrm{mg} / \mathrm{l} \mathrm{PO}_{4}$ & 13.57 & 13.52 & 13.54 & 13.54 \\
\hline 10 & Manganese, $\mathrm{mg} / \mathrm{l} \mathrm{Mn}$ & 3.00 & 3.24 & 3.61 & 3.28 \\
\hline
\end{tabular}

Table 4: Leachate Sample Levels of Heavy Metals compared WHO and FMEnv.

\begin{tabular}{|l|l|l|l|}
\hline PARAMETERS & MEAN & WHO STD & FMEnv \\
\hline Cyanide, $\mathrm{mg} / \mathrm{l} \mathrm{CN}$ & - & 0.10 & NA \\
\hline Magnesium, $\mathrm{mg} / \mathrm{l} \mathrm{Mg}$ & 2.30 & 0.20 & \\
\hline Zinc, $\mathrm{mg} / \mathrm{Zn}$ & 1.43 & 5.00 & 5.000 \\
\hline Copper, $\mathrm{mg} / \mathrm{l} \mathrm{Cu}$ & 18.22 & 1.00 & 0.050 \\
\hline Iron, $\mathrm{mg} / \mathrm{l} \mathrm{Fe}$ & 20.19 & 0.30 & 0.5000 \\
\hline Lead, $\mathrm{mg} / \mathrm{l} \mathrm{Pb}$ & 10.67 & 0.01 & \\
\hline Alkalinity, mg/l CaCO & 1.34 & 200.00 & \\
\hline Nitrate, $\mathrm{NO}_{3}, \mathrm{mg} / \mathrm{l}$ & 1806.00 & 40.00 & \\
\hline Phosphate, $\mathrm{mg} / \mathrm{l} \mathrm{PO}_{4}$ & 27.26 & 5.00 & \\
\hline Manganese, $\mathrm{mg} / \mathrm{l} \mathrm{Mn}$ & 13.54 & 0.05 & 0.050 \\
\hline
\end{tabular}


Panahpour et al. (2011) observed that high concentration of heavy metals bioaccumulate, reduce the soil $\mathrm{pH}$, increase the electrical conductivity and alter the prosperities and fertility of soil thereby compromising the integrity of the soil. Cyanide concentration in the leachate analyzed ranged from $2.33 \mathrm{mg} / \mathrm{l}-2.55 \mathrm{mg} / \mathrm{l}$. this was found to be above the set limit of WHO of $0.10 \mathrm{mg} / \mathrm{l}$. Careful treatment is needed because high concentration of cyanide is harmful to human which may affect respiratory tissues, resulting in asphyxia, chronictoxicity and irritation will cause malaise (Eka et al., 2013). The manganese concentration ranged from $1.08 \mathrm{mg} / \mathrm{l}-1.78 \mathrm{mg} / \mathrm{l}$ which is also above the WHO recommended guideline/limit of $0.20 \mathrm{mg} / \mathrm{l}$. Zinc concentration ranged from $18.05 \mathrm{mg} / \mathrm{l}-18.38 \mathrm{mg} / \mathrm{l}$ which is way too far above $5.00 \mathrm{mg} / \mathrm{l}$ WHO guidelines/limit. The elevated level of $\mathrm{Zn}$ could be traced to dumping of automobile batteries, scraps and fluorescent lamps while the elevated level of $\mathrm{Cu}$ could be traced to usedcement bags in the dumpsite (Masoud et al., 2009).

Iron and lead concentrations read $10.67 \mathrm{mg} / \mathrm{l}-10.82 \mathrm{mg} / \mathrm{l}$ and $1.27 \mathrm{mg} / \mathrm{l}-1.41 \mathrm{mg} / \mathrm{l}$ respectively. These also were found to exceed the WHO set limit of $0.30 \mathrm{mg} / \mathrm{l}$ and $0.01 \mathrm{mg} / \mathrm{l}$ respectively. The concentration of iron and lead seen in the leachate samples is evidence of dumping of iron and steel scraps wastes as well as paints, batteries, photograph and paints processing chemicals in the dumpsite (Mor et al., 2005; Moturi et al., 2004).

\section{Conclusions and Suggestion}

The $\mathrm{pH}$, the BOD5/COD ratios $(0.1 \mathrm{mg} \mathrm{L}-1)$ indicate that this open dumpsite is partially old and stable. Most of parameters in the leachate exceeded the permissible limit required for treated wastewater discharge determined by WHO and FMEnv Standard. The concentration of heavy metals in the Ihiagwa - Nekede open dumpsite leachate is above the standard acceptable levels of treated wastewater discharge determined by the local standard. The concentration of $\mathrm{Pb}$ lies above the permissible limit of $0.2 \mathrm{mg} \mathrm{L}-1$, which is required for treated wastewater discharge determined by local standard. The presence of heavy metals and also the content of nitrate and other ions need to be examined both in the leachates and groundwater from borehole in the area to prevent and reduce effluent of leachate in dumpsite to this groundwater system. For example, high ammonia concentrations can lead to disruption of water bodies such as wells or shallow groundwater. The concentrations of $\mathrm{Pb}, \mathrm{Ni}, \mathrm{Cu}, \mathrm{Cd}$, $\mathrm{Cl}, \mathrm{Ca}, \mathrm{Mg}, \mathrm{NH} 3$, hardness and Total Dissolved Solid (TDS) are quite high in the three samples and might reveal the contamination of nearby borehole waters. Due to the high concentrations of the pollutants in the leachate, an urgent leachate treatment at this site is recommended to prevent contamination to surface and groundwater. In conclusion, an understanding of the characteristics of the leachate is expected to be used to select appropriate management and economical tools in the management of waste dumpsites. 


\section{REFERENCES}

Abbas, A. A., Jingsong, G., Ping, L. Z., Ya, P. Y. and Al-Rekabi, W. S. (2009). Review on Landfill Leachate Treatments.Am.J.Applied Sci., 6:672-684.

Abu-Rukah,Y., Al-Kofahi, O., (2001). The assessment of the effect of landfill leachate on ground-water quality - a case study El-Akader landfill site-north Jordan. J. Arid Environ. 49, 615-630.

Alloway, B. J., Ayres, D. C. (2007). Chemical Principles of Environmental Pollution (Revised Edition), Waste and Other Multipollutant Situation, pp357.

Al-Yaqout, F. and Hamoda, M. F. (2003). Evaluation of landfill leachate in arid climate-a case study. Environment International, Vol. 29,No. 5,pp. 593-600.

Baun, A., Jensen, S.D., Bjerg, P., Christensen, T.H., Nyholm, N., (2000). Toxicity of organic chemical pollution in groundwater down gradient of a landfill (Grindsted, Denmark). Environ. Sci. Technol. 34, 1647-1652.

Eka Sri Yusmartini ,DediSetiabudidaya , Ridwan , Marsi and Faizal (2013)Characteristics of Leachate at Sukawinatan Landfill, Palembang, Indonesia. J. Phys.: Conf. Ser. 423 012048 .

Etim, E. U. and Onianwa, P. C. (2013)Leachate Quality Characteristics: A Case Study of Two Industrial Solid Waste Dumpsites. Journal of Environmental Protection, 2013, 4, 984- $988 \quad$ http://dx.doi.org/10.4236/jep.2013.49113

Esmail Al Sabahi, S. Abdul Rahim, W.Y. Wan Zuhairi, Fadhl Al Nozaily and Fares Alshaebi(2009). The Characteristics of Leachate and Groundwater Pollution at Municipal Solid Waste Landfill of Ibb City, Yemen. American Journal of Environmental Sciences 5 (3): 256-266, 2009 ISSN 1553-345X

H. I. Ezeigbo. Towards efficient water resources management in Nigeria. Water Resources, 1990, 2(1): $40-42$

Huan-jung, F., Shu, H.Y., Yang, H.S., Chen, W.C., (2006). Characteristics of landfill leachates in central Taiwan. Taiwan Sci. Total Environ. 361, 25-37.

Kjeldsen, P., Barlaz, M.A., Rooker, A.P., Baun, A., Ledin, A., Christensen, T. H. (2002). Present and Long Term Composition of MSW Landfill Leachate: A Review, Critical Reviews in

Environmental Science and Technology, 32:297-336.

Maiti, S.K., (2004). Hand Book of Methods in Environmental Studies, vol. 1, Water and Waste Water Analysis. ABD Publishers, India.

Mor, S., Ravindra, K., Chandra, R.P., (2006). Leachate characterization and assessment of groundwater pollution near municipal solid waste landfill site. Environ. Monit. Assess. $118,435-456$.

Massoud, M. A., Tarhini, A., \& Nasr, J. A. (2009). Decentralized approaches to wastewater 
treatment and management: Applicability in developing countries. Journal of Environmental Management, Vol. 90, (2009), pp. 652-659.

Moturi, M. C. Z., Rawat, M. and Subramanian, (2004). 'Distribution and ffactionation of heavy metals in solid waste from selected sites in the industrial belt of Delhi, India', Environ. Monit. Assess. 95, $\wedge^{\wedge} 2>-199$.

Nanny, M.A., Ratasuk, N., (2002). Characterization and comparison of hydrophobic neural and hydrophobic acid dissolved organic carbon isolated from three municipal landfill leachates. Water Res. 36, 1572-1584

Poon, C.S., Chen, Z.Q., (1999). Comparison of the characteristics of flow through and flowaround leaching tests of solidified heavy metal wastes. Chemosphere 38 (3), 663-680

Purwanta W 2007 Leachate Treatment Technology Review in Landfills (Landfill) MSW JAI3 No. 1

Panahpour, E., Gholami, A., Davami, A. H. (2011). Influence of Garbage Leachate on Soil Reaction, Salinity and Soil Organic Matter in East of Isfahan. World Academy of Science, Engineering andTechnology, 171 -176

Rahman, A., L. Hossain, A. Rubaiyat, S. A. Mamun, Z. A. Khan, M. Sayem, and M. K. Hossain. 2013. "SolidWaste Generation, Characteristics and Disposal at Chittagong University Campus, Chittagong, Bangladesh.’Discovery Science 4 (11): 25-30.

Urase, T., Salequzzaman, M., Kobayashi, S., Matsuo, T., Yamamoto, K., Suzuki, N., (1997). Effect of high concentration of organic and inorganic matter in landfill leachate on the treatmentof heavy metals in very low concentration level. Water Sci. Technol. 36 (12),349-356.

WHO (2009) Calcium and magnesium in drinking water: public health significance. World Health Organization press, Spain, p 194. http://whqli bdoc.who.int/publications/2009/97892 41563 550eng.pdf 32, 297-336. 